University of Nebraska - Lincoln

DigitalCommons@University of Nebraska - Lincoln

Journal for the Advancement of Developing

Economies

Economics Department

2012

\title{
Measuring Water Poverty Index in Urban Areas of Punjab
}

\author{
Kanwal Zahra \\ University of Central Punjab \\ Syed Hussain Haider \\ University of Central Punjab \\ Afzal Mahmood \\ Federal Board of Revenue, Lahore, Pakistan \\ Sami Ullah \\ University of Gujrat
}

Follow this and additional works at: https://digitalcommons.unl.edu/jade

Part of the Econometrics Commons, Growth and Development Commons, International Economics

Commons, Political Economy Commons, Public Economics Commons, and the Regional Economics

Commons

Zahra, Kanwal; Haider, Syed Hussain; Mahmood, Afzal; and Ullah, Sami, "Measuring Water Poverty Index in Urban Areas of Punjab" (2012). Journal for the Advancement of Developing Economies. 17.

https://digitalcommons.unl.edu/jade/17

This Article is brought to you for free and open access by the Economics Department at DigitalCommons@University of Nebraska - Lincoln. It has been accepted for inclusion in Journal for the Advancement of Developing Economies by an authorized administrator of DigitalCommons@University of Nebraska - Lincoln. 


\title{
Measuring Water Poverty Index in Urban Areas of Punjab
}

\author{
Kanwal Zahra ${ }^{1}$, Syed Hussain Haider ${ }^{1}$, Afzal Mahmood ${ }^{2}$, Sami Ullah ${ }^{3}$ \\ 'University of Central Punjab \\ ${ }^{2}$ Federal Board of Revenue, Lahore, Pakistan \\ ${ }^{3}$ University of Gujrat
}

\begin{abstract}
The urban population of Punjab is growing rapidly. It is projected that there will be a 25 to 30 percent increase in urban population by 2020. This rapid population increase is causing major problems in the efficient provision of urban services in these cities. To evaluate the effect of this population increase, this paper tries to produce an integrated assessment of water stress and scarcity, linking physical estimates of water availability with socioeconomic variables that reflect poverty, i.e., a Water Poverty Index. It is understood that poor households face the problem of the accessibility of potable water, and this results in a significant loss of time and effort, especially for women. On the basis of multiple data sources, this paper evaluates water poverty in three panels of large, intermediate, and small cities of Punjab. The results show the same water poverty level within the panels but a higher poverty level in large cities than small and intermediate cities
\end{abstract}

Keywords: Water scarcity, water poverty, income poverty.

\section{INTRODUCTION}

The world's urban population continues to grow at a very rapid pace due to the increasing trend of socio-economic activities in the urban areas. The world is transforming into a global village and the developing countries are in a run to penetrate the competition of industrialization and are emphasizing different types of subsidies to promote their industry. The promotion of industry and business activities encourages labor to move towards industrialized areas; as a result, the trend of rural-urban migration is increasing. In 2003, it was found that 48 percent of the general population was living in urban settlements. The majority of all urban dwellers were living in smaller urban settlements whereas, less than 5 percent of the world population is living in mega- cities (United Nations, 2003).

The increase in urbanization no doubt is a driving force of economic development, but this expansion of cities also leads to socio-economic and environmental problems. The implications of rapid urbanization and demographic trends for employment, food security, water supply, shelter and sanitation, and especially the disposal of solid and liquid wastes that the cities produce are alarming (United Nations, 2003).

It is expected that the world urban population will rise up to 61 percent of the total population with an average annual rate of 1.8 percent per annum. The intensity of increase in urban population is 
high in developing countries as compared to developed countries. This rapid increase in the urban population is causing urban sprawl and the growth of slums in developing countries. In Punjab, the urban population contains 35 percent of total population with an annual natural growth rate of 2.5 percent and migration rate of 1.5 percent. In the case of five large cities of Punjab ${ }^{1}$, it is projected that there will be a 25 percent increase in the population by $2020^{2}$. The household congestion goes up to 7.1 persons per household. On the basis of these facts, it is estimated that approximately 437,000 families are added every year in Punjab. This rapid increase in population is causing great socio-economic and environmental problems for the residents of urban areas of Punjab.

The water poverty is high in the areas where urban boundaries are expanding rapidly; the increase in urban population leads to increase the number of slums or kachi abadies. These poor communities tend to be less well educated on average (because they do not have the time and resources to obtain an education), and less politically powerful. Their residents are not well informed about the cause-and-effect of poor water management in their areas, which confounds the water scarcity and sanitation problems. Water poverty not only affects the standard of living of these people but also has an impact on their health; different diseases such as malaria and diarrhea are the result of this water poverty. It is found that more than 40 percent of the population of the study area has no access to sewer systems. Therefore, a "septic tank" is the most common disposal facility where excreta and a limited amount of sludge water can be collected for biological digestion. The digested excreta leach into the soil surrounding the tank and hence, subject shallow groundwater to pollution. In addition, part of the agricultural fertilizers used in these areas is usually infiltrated into groundwater (The Urban Unit).

There are 229 urban centers in Punjab, in which five are large (having population 1 million \& above), fourteen are intermediate (having population between 2.5 million to 1 million), eighty- one are small cities (having population 50,000-250,000) and 129 towns which have population less than 50,000 . This composition of urban centers clearly indicates the trend of urbanization in Punjab.

The lack of proper housing, urban services, as well as education and health facilities make this dilemma more critical. It is estimated that only 55 to 60 percent of people in five large cities of Punjab have access to water and sanitation facilities. On the other hand, 45 to 50 percent have access to proper solid waste management facilities. Moreover, 8 to 12 percent of the active population are unemployed in these areas (Urban Unit, 2008). The deprivation from common necessities which determine the quality of life, including food, clothing, shelter and safe drinking water, is high in cities of Punjab. This deprivation also contributes to the factors like opportunities to learn, to obtain better employment to escape poverty, and/or to enjoy the respect of fellow citizens. Such deprivation can be seen in urban areas of Punjab which generate high income inequality in these areas while, at the same time, poverty gap becomes even larger (SPDC, 2008).

On the other hand, there are 900 kachi abadies in which the majority of residents have no basic facilities. 47.5 percent of the total urban population lives in slums $(A D B, 2008)$. At the same time, 35.02 percentage of people live below the poverty line, which is higher than the percentage of people who live below poverty line in rural areas of Punjab $(S P D C, 2008)$. While these conditions of poverty attract the attention of researchers, the issue of water poverty is ignored in Pakistan.

${ }^{1}$ Large city is the city which has more than 300,000 population

${ }^{2}$ Socio-Economic \& Demographic profile of Five Large Cities, The Urban Unit, 2008 


\section{OBJECTIVES OF THE STUDY}

Water management is a complex and difficult task. As the trend of population growth continues, the water resources will be continually stretched, and water management will become increasingly complex. This paper attempts to evaluate the status of water poverty in different cities of Punjab in order to improve the management of this valuable resource. Three panels of large, intermediate and small cities are considered as sample areas for analyzing the water poverty in Punjab.

The basic objectives of this study are:

- To provide a better understanding of the physical extent of water availability

- To suggest a mechanism for the prioritization of water investments

- To give an appropriate tool to monitor progress in the water sector (working towards the United Nation's Millennium Development Goals)

\section{LITERATRE REVIEW}

Sullivan (2002) developed an interdisciplinary approach of calculating water poverty index. She advocates the view that the linkage of physical estimates of water stress and scarcity with socioeconomic variables reflect poverty among poor households. Sullivan focuses on the time and effort loss of poor in seeking of potable water. Through linking physical and social sciences, she established a water poverty index.

Lawrence, Jeremy, and Sullivan (2002) constructed an International Water Poverty Index. The purpose of developing Water Poverty Index is to express an interdisciplinary measure which links household welfare with water availability and indicates the degree to which water scarcity impacts human populations. By using measures of resources, access, capacity, use and environment, they obtained the measures for 140 countries. This water poverty index helps the national and international organizations concerned with water provision and management to monitor both the resources available and the socioeconomic factors which impact access to and use of those resources.

Heidecke (2006) tried to make an application of the Water Poverty Index (WPI) as a monitoring tool for Benin's water sector. She focused on the process of political decentralization shifting responsibility for and administration of rural water supplies from the national to the communal level. In order to meet this challenge, appropriate indicators are needed for monitoring and analyzing the progress of the water sector for each community. She made an analysis of Benin water project called IMPETUS project. Results show a clear distinction between communes in the northern and the southern areas of the country and WPI rankings are similar to those for poverty levels. She also highlights the strengths and weaknesses of the WPI and suggests improvements for its application at the communal level.

\section{METHODOLOGY}

The Water Poverty Index (WPI) is an integrated tool that is mainly relevant at the community, municipal and district level. It is very helpful to determine priorities for action and to monitor 
progress towards targets. There is a need to introduce an interdisciplinary approach to monitor the progress in the water sector, which involves both qualitative and quantitative assessments. The approach represents the views of stakeholders and addresses the wide range of issues that exist in the water sector. In order to see how a community, country or region is progressing over time, a monitoring system based on simple indicators is essential. The WPI provides such a simple and easy-to-use indicator for the water sector. It can be used by water managers and planners. Furthermore, at the community level, it is also possible for people to apply it to their own situations to understand how water can best be managed to meet their own needs and to lobby for action (Sullivan, Jeremy \& Lawrence, 2005).

Water availability is important for measuring and monitoring because people can be prevented from accessing it in many ways. People can be 'water poor' in the sense of not having sufficient water for their basic needs because it is not available. Or, they may need to dedicate a lot of time in order to access potable water; supplies may be limited for various reasons. People can also be 'water poor' because they are 'income poor.' Although water is available, they cannot afford to pay for it (Sullivan et. al, 2003).

This study will use Pressure-State-response model introduced by OECD in 1993 because it provides a causal chain that links indicators of pressures to state indicators and to indicators of societal response. In 1996, Australia adopted the Pressure-state-Response Framework. Harrison and Pearce (2000) refined this model by explaining indicators related to pressure, state and response. More recently, Garriga and Foguet (2008) used this pressure-state-response model in finding the water poverty index in China.

The water poverty index is constructed from a series of variables to capture the essence of what is being measured. This can be done using national scale data (a top-down approach), or at a local level, using locally determined values and parameters (a bottom-up approach). Using the composite index approach, the WPI could comprise various elements:

1. Resource

2. Access

3. Capacity Use

4. Environment 


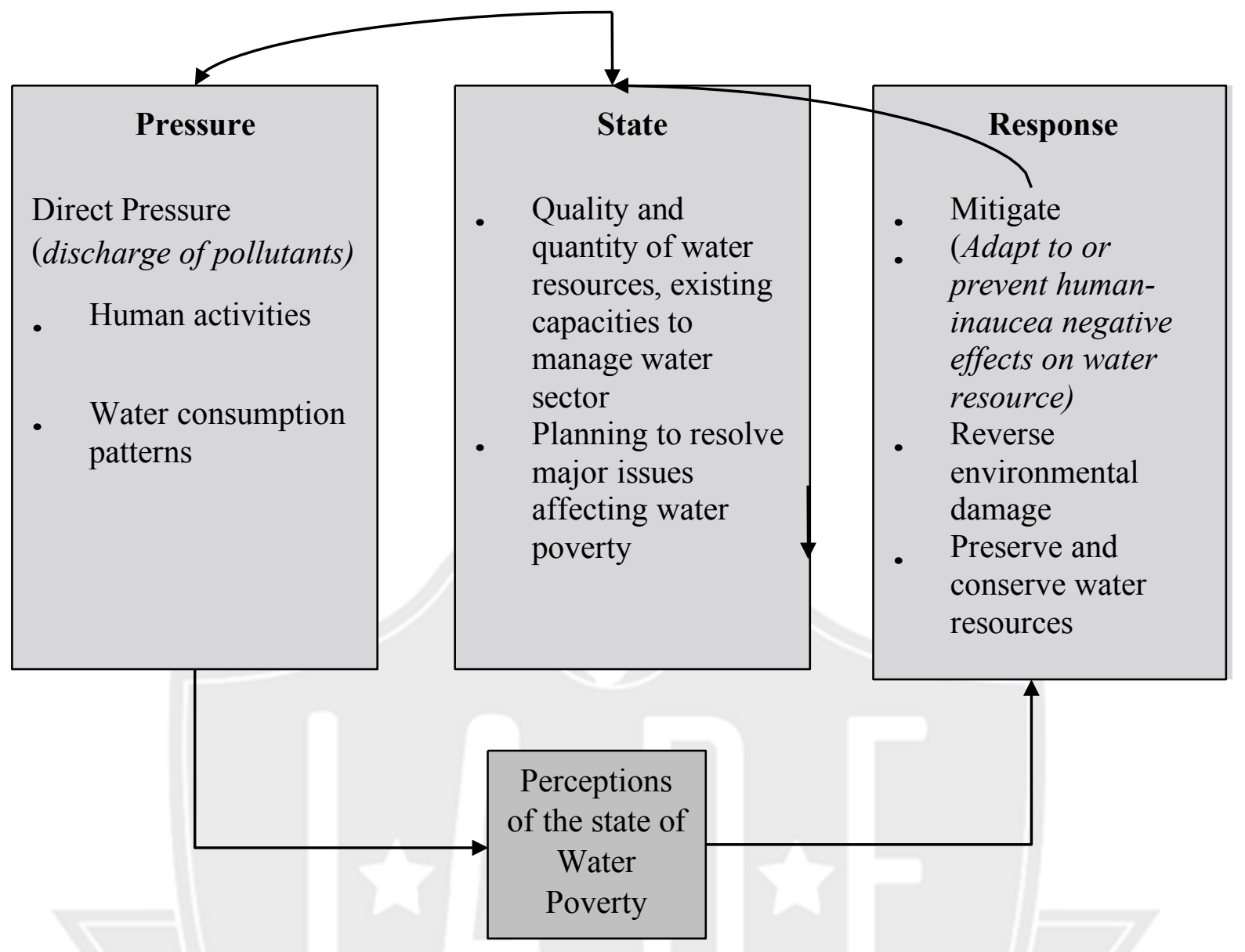

Figure 1: Pressure-State-Response Model

Table 1: Water Poverty Index Components

\begin{tabular}{|l|l|}
\hline $\begin{array}{l}\text { TWPI } \\
\text { aComponent }\end{array}$ & Variable \\
\hline Resources (R) & $\begin{array}{l}\text { Water resources availability (Variability or reliability of water resources) } \\
\text { Water quality } \\
\text { Integrated Water Resources Management (sustainability criterion) }\end{array}$ \\
\hline Access (A) & $\begin{array}{l}\text { Access to safe water as a percentage of population Access to sanitation as } \\
\text { a percentage of population Equity in access (sustainability criterion) }\end{array}$ \\
\hline Capacity (C) & $\begin{array}{l}\text { Water sector institutional framework } \\
\text { Financing strategies and cost-recovery (sustainability criterion) Gender } \\
\text { issues and the role of women (sustainability criterion) }\end{array}$ \\
\hline
\end{tabular}




\begin{tabular}{|l|l|}
\hline Use (U) & $\begin{array}{l}\text { Domestic water consumption rate Prevalence of water-related diseases } \\
\text { Agricultural water use } \\
\text { Water use efficiency (sustainability criterion) }\end{array}$ \\
\hline Environment (E) & $\begin{array}{l}\text { Environmental regulation and management Water stress. pollution } \\
\text { (sustainability criterion) }\end{array}$ \\
\hline
\end{tabular}

The concept of water poverty is assumed to be a function of physical availability of water resources $(\mathrm{R})$, extent of access to water (A), capacity to manage water (C), ways in which water is used for different purposes (U), and the need to allocate water for ecological services (E). Considering that it is a dynamic and holistic concept, a pressure-state-response model has been applied to those five components in a matrix scheme. Numerically, the equation for the enhanced WPI is presented below:

$\mathrm{WPI}=(\mathrm{R}+\mathrm{A}+\mathrm{C}+\mathrm{U}+\mathrm{E}) / 5$

Equal weights are used for all indicators; a scoring range between 0 and 1 is assigned to each parameter or combination of indicators. Both the quantitative and qualitative parameters are divided in four scale scores $(0.25,0.50,0.75$, and 1.0$)$, where a value of 0 is assigned to the poorest level and 1 to optimum conditions. This allows for the use of spreadsheets instead of equations or other complex functions. The full description of levels and scores of all parameters is briefly discussed in appendix 1 and in tables 2,3 , and 4, respectively.

The 'resource' component measures availability of water resources. The increase in population educational level, high values of HDI-Education places greater pressure on water resources, and it has been taken as the pressure parameter. Likewise, water quality is also an important factor influencing resource accessibility, an aspect that has also been considered. The response parameter is assumed to be the city's education attainment. The population Census 1998, SPDC and Town Municipal Authority (TMA) provides the required data to measure resource indicators for WPI.

In the 'access' indicator there are two sets of parameters: one relative to access to safe water and the other to improved sanitation. The MICS (2007-08) and TMA have provided relevant data to assess the percentage of populations that have access to basic services. The response parameter is based on analyzing suitability of infrastructure to treat water for domestic purposes and sewage before its discharge to the environment.

The human development within the city is taken as a main indicator to judge the capacity of residents and institutes of that city. The water sector institutional capacity is also considered for this purpose. It is generally believed that services are better sustained when all potential users (both women and men, poor and better off) influence the process of service establishment (Gross, Mukjerjee \& Wijk, 2000). Therefore, the pressure parameter is related to the percent of educated household heads since this is an indication of how household are being empowered within the community. MICS (2007-08 \& 2003-04) provide the education attainment of that community. The 
response parameter is taken as the wealth (as derived from using the durable belongings of household).

The 'use' component focuses on the consumption of water in households as well as in different productive sectors such as industry and agriculture. The pressure parameter is based on prevalence of water-related diseases as a measure of inadequate water use and poor hygienic practices (Garriga and Foguet, 2008). Since the main demand of water is for agricultural use, the state parameter is estimated by the proportion of irrigated land to total cultivated land. On a sustained basis, wateruse efficiency has been evaluated as a response parameter.

In order to measure the environmental impact, one must take into consideration different aspects of water use (i.e. environment related institutional framework, people using un-hygienic or unimproved source of water, green area within the city). The total impact is then a function of number of pollutant sources and their individual impact. This state parameter is correlated to the percentage of total area under natural vegetation in the city. The response indicator is estimated by analyzing implementation of sector-related policies to protect the environment as well as the envisaged basin sector expenditures. It should reflect the response by stakeholders and decision- makers in tackling environmental problems.

\section{RESULTS}

The Water Poverty Index (WPI) in Punjab is calculated in randomly selected cities from all areas of Punjab. Three panels of five large cities, five intermediate cities and five small cities were taken in order to evaluate water poverty in Punjab. It should be noted that aimed at setting a methodology replicable within different contexts, the selection of indicators has been not only based on what is desirable to measure, but on the need to use existing, consistent and available data. After data compilation, information has been classified following the WPI-PSR framework. Once the parameters of all five components are obtained, the WPI is calculated according to Eq.1. The results are presented in Table 5.

\section{Table 5: WPI in selected Cities of Punjab}

\begin{tabular}{|l|ll|l|l|l|ll|}
\hline & Cities & Resource & Access & Capacity & Use & Environment & WPI \\
\hline \multirow{5}{*}{ Large Cities } & Lahore & 0.75 & 0.5 & 0.5 & 0.5 & 0.5 & 0.55 \\
\cline { 2 - 8 } & Gujranwala & 0.75 & 0.25 & 0.5 & 0.25 & 0.25 & 0.40 \\
\cline { 2 - 7 } & Faisalabad & 0.75 & 0.25 & 0.5 & 0.5 & 0.5 & 0.50 \\
\cline { 2 - 8 } & Rawalpindi & 0.75 & 0.25 & 0.5 & 0.25 & 0.5 & 0.45 \\
\cline { 2 - 7 } & Multan & 0.5 & 0.25 & 0.5 & 0.5 & 0.5 & 0.45 \\
\hline Intermediate & Sargodha & 0.75 & 0.25 & 0.5 & 0.25 & 0.5 & 0.45 \\
\hline & Bahawalpur & 0.25 & 0.25 & 0.25 & 0.25 & 0.5 & 0.30 \\
\hline & Gujrat & 0.75 & 0.25 & 0.5 & 0.25 & 0.25 & 0.4 \\
\hline & R.Y.Khan & 0.25 & 0.25 & 0.25 & 0.25 & 0.25 & 0.25 \\
\hline & D.G. Khan & 0.25 & 0 & 0.25 & 0.25 & 0.25 & 0.20 \\
\hline
\end{tabular}




\begin{tabular}{|l|l|l|l|l|l|l|l|}
\hline Small Cities & Chakwal & 0.75 & 0.25 & 0.5 & 0.25 & 0.25 & 0.4 \\
\hline & Rajanpur & 0 & 0 & 0.25 & 0.5 & 0.25 & 0.20 \\
\hline & Layyah & 0.5 & 0.25 & 0.5 & 0 & 0.25 & 0.3 \\
\hline & Khushab & 0.5 & 0.25 & 0.5 & 0.5 & 0.5 & 0.45 \\
\hline & Attock & 0.5 & 0.25 & 0.5 & 0.5 & 0.25 & 0.40 \\
\hline
\end{tabular}

To illustrate the complexity of water issues, a pentagram has been developed below in Figure 2, which shows the values of all five components in a visually clear way. The pentagram directs attention to those water sector needs that require urgent policy attention. Likewise, different pentagrams for the Pressure - State - Response also has been developed for separate panels of large, small, and intermediate cities of Punjab to show the separate status of pressurestate- response components of each city category. The figure below shows a combined picture of water poverty in different cities of Punjab.

Although the WPI of different panels shows almost same result within panels, different conclusions can be achieved if a thorough analysis of the five index components or on a specific position within the causal chain is conducted. It highlights the fact that "when observed separately the indicators offer a good view of the situation in that field; and when merged into one component, more information may be lost than gained," (Komnenic, 2007). But in comparative analysis of panels, large cities show high water poverty which may be due to high population density, urban sprawl, and an increase in kachi abadies in these areas. In the five large cities of Punjab, there is a proper water management body called Water and Sanitation Agency (WASA) worked under housing authority. The high-water poverty index leads to a different conclusion. WASA is not using metering systems to regulate its operating system, as evidenced by the fact that only a few localities have proper water meters; this operational deficiency increases the risk that WASA will face fiscal deficit. Additionally, in Punjab, there is no proper institutional framework implemented in the water

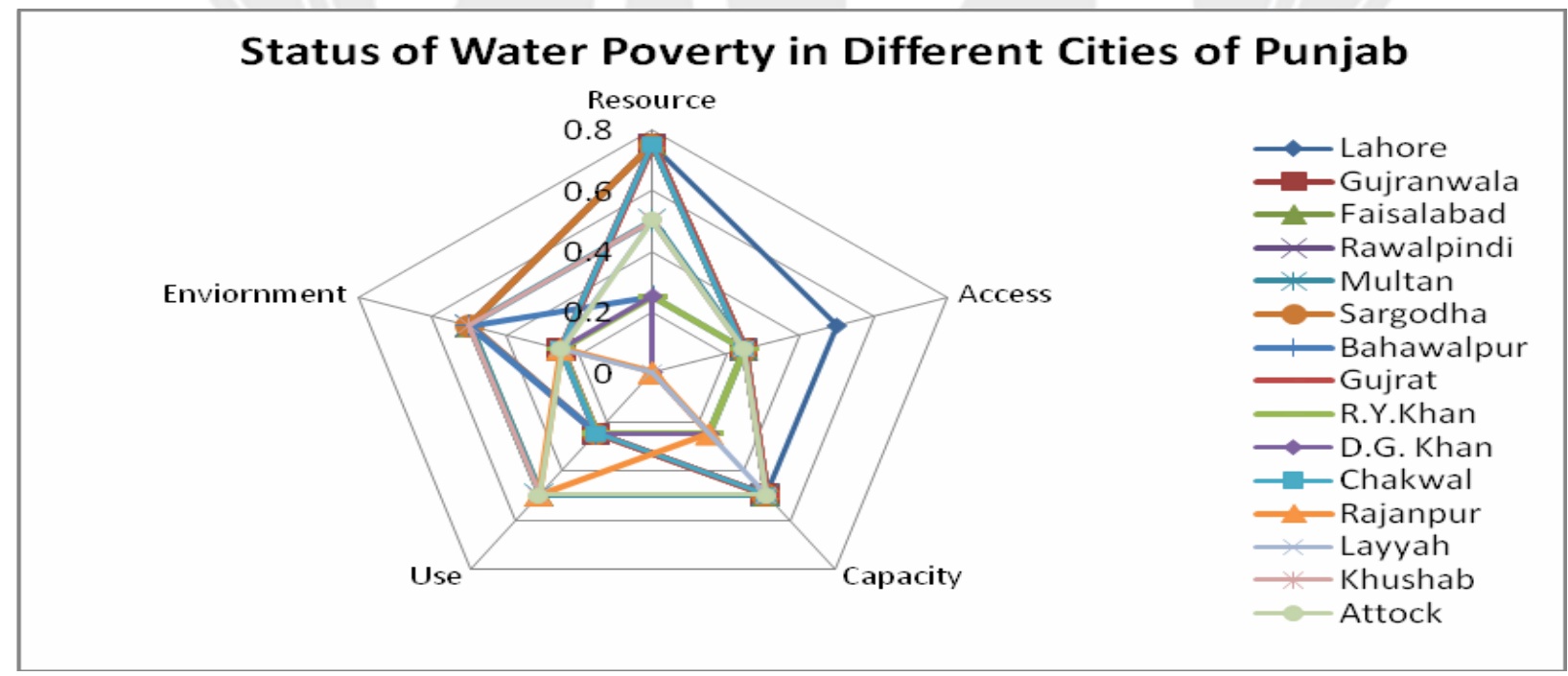

Figure 2: Status of Water Poverty in Different Cities of Punjab

sector; even the water agencies and TMAs have no proper water act or water framework to regularize their operation. Another factor contributing to the high-water poverty in Punjab is the 
lack of treatment before the disposal of sewerage water; such a treatment plant only exists in Faisalabad, but it does not cover the whole city. As our discussion here illustrates, the water poverty is high in Punjab due to an array of gives factors which are caused due to poor water management policies. The results lead to the conclusion that there is a need of a proper and thorough planning to manage water resources and water demand within the cities.

\section{DISCUSSION}

Urban growth is an important criterion of achieving economic development in a country. To manage this rapid urbanization, a sound planning and monitoring framework is needed. In developing countries, the trend towards urbanization is greater than in developed ones. However, without proper infrastructure to plan and manage it this trend creates many different barriers to service delivery. Additionally, it results in an increase in income inequality among the residents of urban areas. This paper attempts to introduce an important tool to manage water resources as well as to introduce water policies in accordance with the needs of different areas. For this purpose, three panels of large, small, and intermediate cities were selected as sample areas of study. Multiple data sources consult to gather maximum information of this subject.

Water Poverty Index (WPI) is a new subject of concerns for researchers; there is a dire need to have a focus research on evaluating water poverty as it proves as an important tool to monitor water projects in different areas and establish priorities for new projects. There is a need to develop an index which is non-scale-dependent; geo-referenced datasets should provide the appropriate framework to assess WPI at any point on the map regardless of the scale. Within such a framework, detailed and accurate data from both the social and physical sciences could be linked in an integrated way for any specific point on the map (identified by its grid reference).

This would be an important asset for WASA in five large cities and WATSAN in other cities of Punjab.

The water poverty index shows greater values in large cities and lower values in small cities. The value differences may lead to the conclusion that the expansion of spatial boundaries of cities and increase in slums and un-planned localities create serious problems for water agencies to manage water sources and demand in these areas. On the other hand, this study only considers the indicators that are available. On the other hand, there are other approaches of executing water poverty analyses as well; hence, the doors are open for further research.

\section{REFERENCES}

Garriga, G. R., \& Agustí, P. F. (2008). Enhancing the water poverty index: Towards a meaningful indicator. UPC, Barcelona.

Gross, B., Mukherjee, N. \& Wijk, C. (2000). Linking sustainability with demand, gender and poverty: A study in community-managed water supply projects in 15 countries. IRC and The World Bank - Water and Sanitation Program, Washington, DC.

Harrison. P. \& Fred P. (2000). AAAS atlas of population \& environment. American Association for the Advancement of Science, University of California.

Heidecke, C. (2006). Development and evaluation of a regional water poverty index for Benin. 
International Food Policy Research Institutes, Washington, DC.

Jamal. H. (2007). Income poverty at district level: An application of small area estimation technique. Pakistan Economic and Social Review, Research Report No 70, Karachi.

Jamal. H \&Amir, J. K. (2007). Trends in regional human development indices, Pakistan economic and social review. Research Report No 70, Karachi.

Khan. J. A \& Haroon. J (2007). Indices of multiple deprivation 2005. Social Policy and Development Centre, Research Report No. 72, Karachi.

Komnenic, V., Ahlers, R. \& van der Zaag, P. (2008). Assessing the usefulness of the Water Poverty Index by applying it to a special case: Can one be water poor with high levels of access? Physics and Chemistry of the Earth.

Lawrence, P., Jeremy M. \& Sullivan, C. (2002). The Water Poverty Index: an international comparison. Keele University, Staffordshire.

Multiple Indicator Cluster Survey (2007-08). Punjab Bureau of Statistics, Lahore.

OECD (Organisation for Economic Co-operation and Development) (1993). Core set of indicators for environmental performance reviews: A synthesis report by the group on the state of the environment. Report No. 83, OECD, Paris.

Poverty and Social Impact Assessment Study (2009). The Urban Unit, P\&D Department, Lahore.

Social Development in Pakistan. (2005). Social Policy Development Centre, Karachi. Sullivan, C. (2002). Calculating a Water Poverty Index. World Development, Vol. 30, No. 7.

Sullivan, C. Jeremy M. and Lawrence, P. (2005). Application of the Water Poverty Index at different scales: A cautionary tale. Keele University, Staffordshire.

Whiteman, W. (2006). Water Management in Urban Centers. Water Resource Development, VOL 22, No 18.

World Urbanization Prospects (2005). Department of Economics and Social Affairs. United Nation.

\section{APPENDIX 1}

Table 2: Description of WPI-Pressure Indicators

\begin{tabular}{|llll|}
\hline Indicator & Pressure Parameters & Level & \multicolumn{1}{l|}{ Value } \\
\hline Resources & Annual Population Growth (PG) Rate in the lastPG $>4 \%$ & 0 \\
& 2 years, in $\%$ and weighted by population & $4 \%>\mathrm{PG}>2 \%$ & 0.25 \\
& & $2 \%>\mathrm{PG}>0 \%$ & 0.50 \\
& & $0 \%>\mathrm{PG}>-2 \%$ & 0.75 \\
& $-2 \%>\mathrm{PG}$ & 1.00 \\
\hline Access (safe water) & Variation in safe water accessibility in the last $2 \mathrm{I}<-10 \%$ & 0 \\
& years, weighted by population & $-10 \%<\mathrm{I}<0 \%$ & 0.25 \\
& & $0 \%<\mathrm{I}<10 \%$ & 0.50 \\
& & $10 \%<\mathrm{I}<20 \%$ & 0.75 \\
Access & $\mathrm{I}>20 \%$ & 1.00 \\
sanitation) & & $-10 \%<\mathrm{I}<0 \%$ & 0.25 \\
& & $0 \%<\mathrm{I}<10 \%$ & 0.50 \\
& & $10 \%<\mathrm{I}<20 \%$ & 0.75 \\
& & $\mathrm{I}>20 \%$ & 1.00 \\
\hline
\end{tabular}




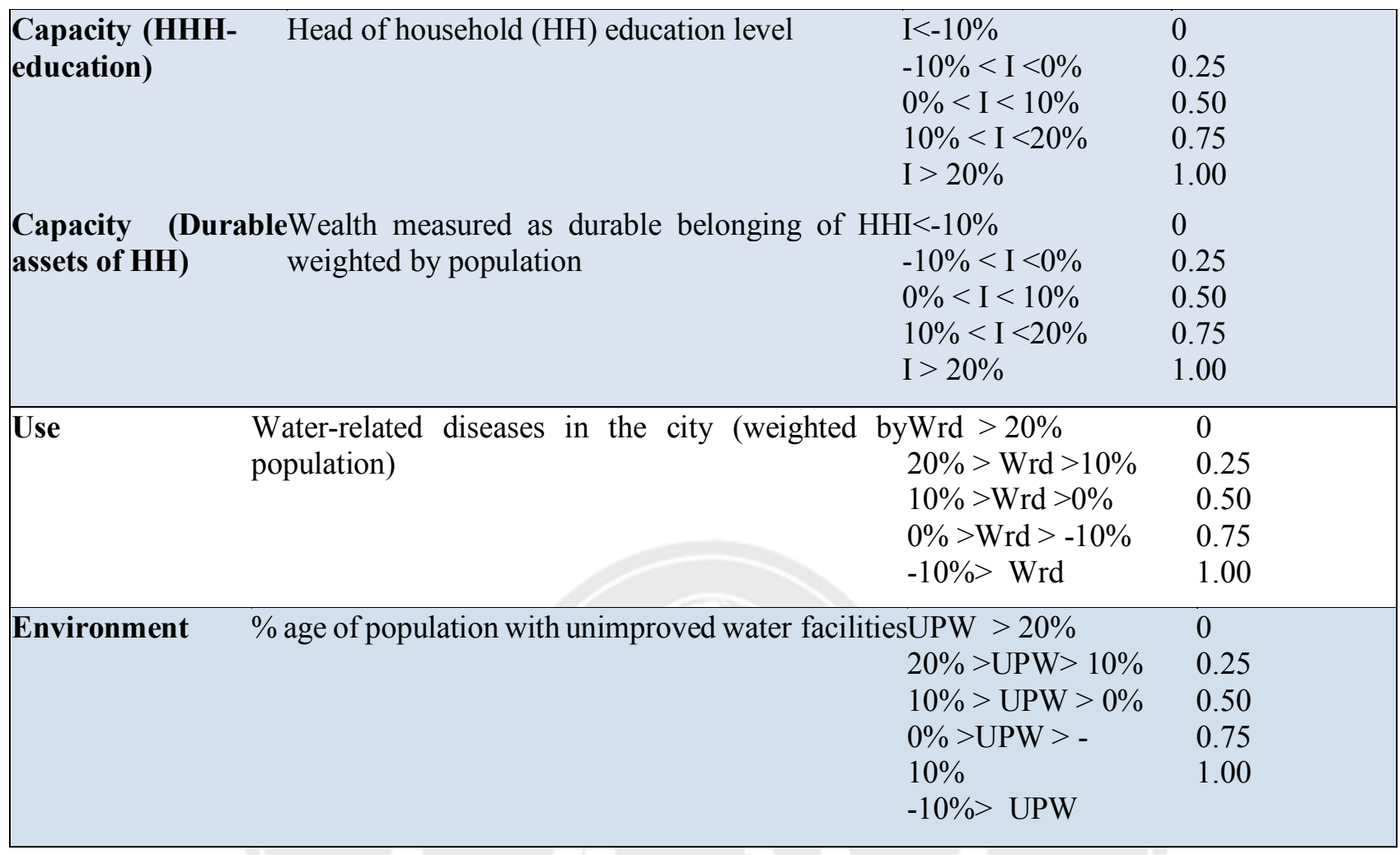

Table 3: Description of WPI-State Indicators

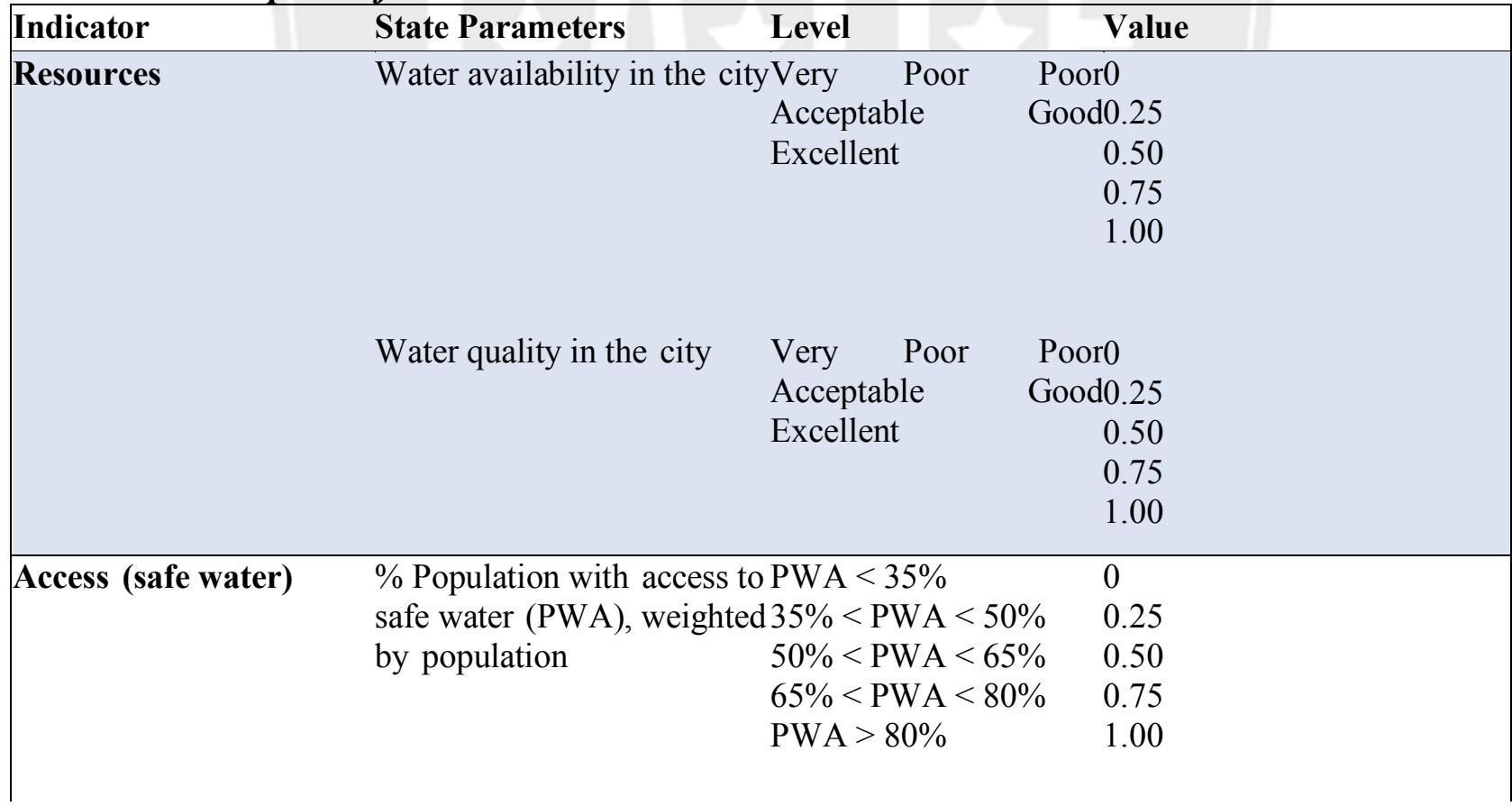




\begin{tabular}{|c|c|c|c|}
\hline $\begin{array}{l}\text { Access } \\
\text { (improved sanitation) }\end{array}$ & $\begin{array}{l}\% \text { Population with access to } \\
\text { improved sanitation (PSA), } \\
\text { weighted by population }\end{array}$ & $\begin{array}{l}\mathrm{PSA}<35 \% \\
35 \%<\mathrm{PSA}<50 \% \\
50 \%<\mathrm{PSA}<65 \% \\
65 \%<\mathrm{PSA}<80 \% \\
\mathrm{PSA}>80 \%\end{array}$ & $\begin{array}{l}0 \\
0.25 \\
0.50 \\
0.75 \\
1.00\end{array}$ \\
\hline Capacity & HDI of city & $\begin{array}{l}\text { HDI }<0,4 \\
0,40<\mathrm{HDI}<0,55 \\
0,55<\mathrm{HDI}<0,70 \\
0,70<\mathrm{HDI}<0,85 \\
\text { HDI }>0,85\end{array}$ & $\begin{array}{l}0 \\
0.25 \\
0.50 \\
0.75 \\
1.00\end{array}$ \\
\hline Use & $\begin{array}{l}\text { Agricultural water use (WU), } \\
\text { expressed as the proportion of } \\
\text { irrigated land to total cultivated } \\
\text { land }\end{array}$ & $\begin{array}{l}\text { WU }>85 \% \\
85 \%>\text { WU }>70 \% \\
70 \%>\text { WU }>55 \% \\
55 \%>\text { WU }>40 \% \\
40 \%>\text { WU }\end{array}$ & $\begin{array}{l}0 \\
0.25 \\
0.50 \\
0.75 \\
1.00\end{array}$ \\
\hline Environment & $\begin{array}{l}\% \text { of city's area under natural } \\
\text { vegetation }(\mathrm{Av})\end{array}$ & $\begin{array}{l}\text { Av }<15 \% \\
15 \%<\mathrm{Av}<30 \% \\
30 \%<\mathrm{Av}<45 \% \\
45 \%<\mathrm{Av}<60 \% \\
\mathrm{Av}>60 \%\end{array}$ & $\begin{array}{l}0 \\
0.25 \\
0.50 \\
0.75 \\
1.00\end{array}$ \\
\hline
\end{tabular}

Table 4: Description of WPI-Response Indicators

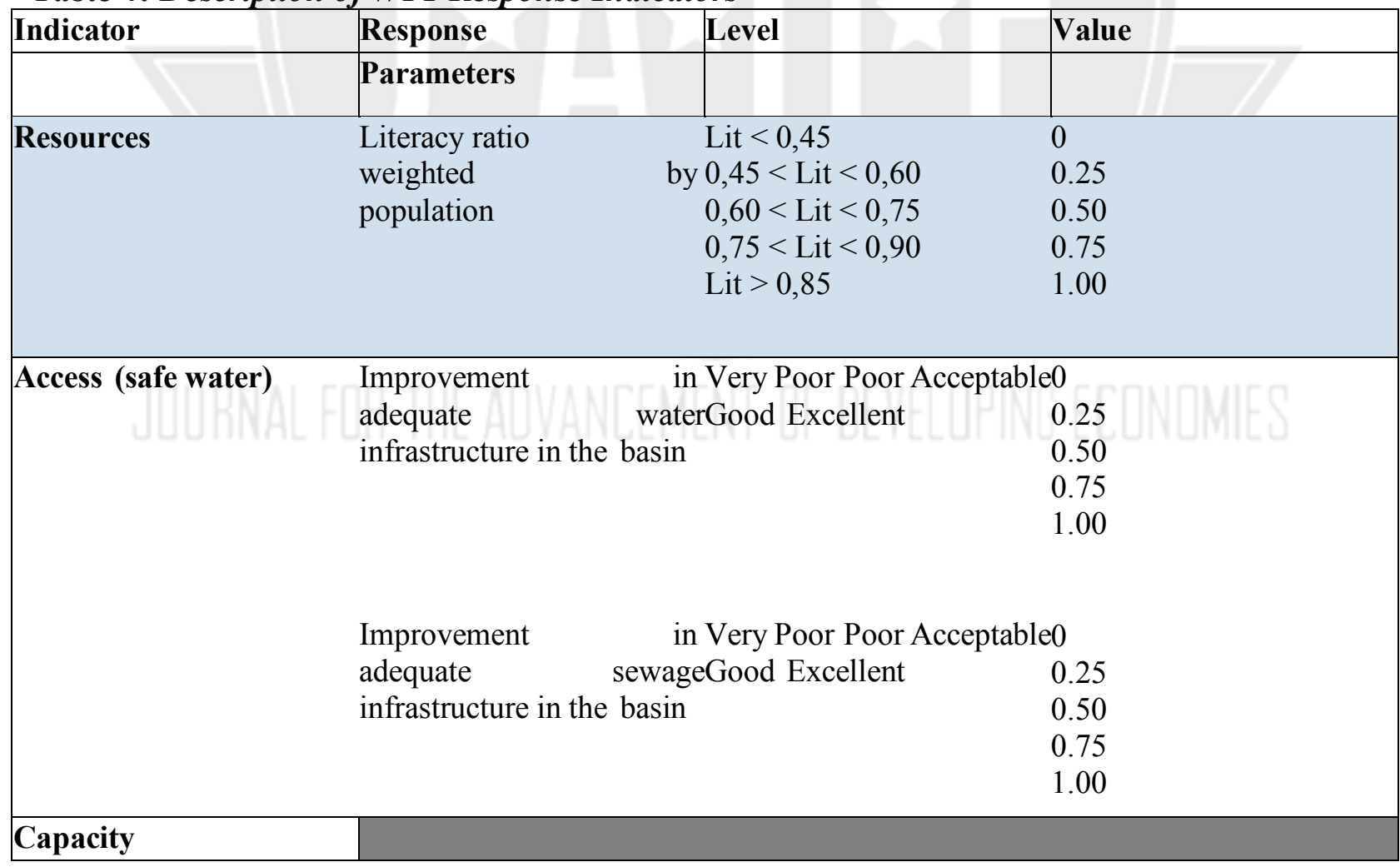




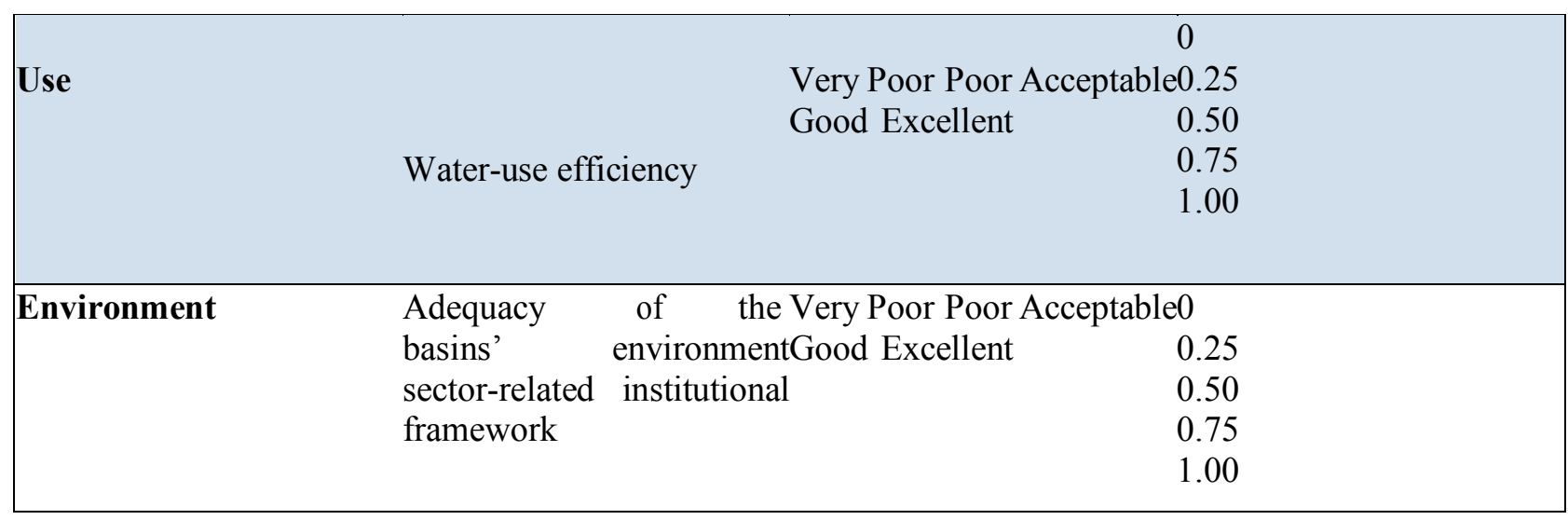

